\title{
Private Military and Security Labour Migration: The Case of Fiji
}

\author{
Yoko Kanemasu* and Gyozo Molnar**
}

\begin{abstract}
Private military and security companies (PMSCs) are a fast-growing global industry. While the rise of PMSCs and their activities have attracted much media coverage and growing scholarly attention, little is known about their sourcing of masses of military labour from the global South. This exploratory study examines the case of Fiji, whose thousands of ex/current disciplinary force personnel and unemployed men have been contracted by PMSCs to provide security work in Iraq and other high-conflict areas. The article shows this to be an instance of unequal core-periphery military labour trade, outlining its scale, processes and impacts on the migrants. It also illuminates how the migrants' collective agency is demonstrated even under powerful structural constraints.
\end{abstract}

\section{INTRODUCTION}

While mercenaries have existed for centuries, today's private military and security companies (PMSCs) ${ }^{1}$ emerged in the early 1990s, "driven by three dynamics: the end of the Cold War, transformations in the nature of warfare that blurred the lines between soldiers and civilians, and a general trend toward privatisation and outsourcing of government functions" (Singer, 2005). PMSCs, although presented as civilian security providers, have not only taken over support functions such as transport, logistics and maintenance from militaries, but also provided armed protection to individuals and sites, and undertaken armed security operations akin to those conducted by military forces (Bjork and Jones, 2005).

PMSC combat operations in Angola and Sierra Leone drew much attention in the 1990s, followed by a surge in the use of PMSCs by the US and coalition governments in Afghanistan and Iraq in the wake of the US-led invasions. 30,000 and 24,000 armed contractors were in Iraq and Afghanistan respectively in 2010 (Krahmann, 2012). Today, with the American/coalition forces withdrawing from Iraq and Afghanistan, the security vacuum is being filled by PMSCs, who continue to find extensive demand especially for private-sector protection (Sen, 2015). Del Prado (2008) estimates the industry's annual yield at US\$100-120billion.

There has been considerable journalistic coverage and civilian protest concerning PMSC activities, especially incidents of abuse and other transgression. This is paralleled by growing scholarly literature investigating the growth of PMSCs as a manifestation of Western state-corporate expansionism (Whyte, 2003), their impact on peacebuilding/peacekeeping (Bjork and Jones, 2005; Brayton, 2002), their ambiguous legality and regulatory frameworks (Krahmann, 2012) and the accountability of their conduct (Peters, 2006; Francis, 1999). Recently, Fraser (2013) shed new

\footnotetext{
* University of the South Pacific, Fiji

** University of Worcester
} 
light on the industry by highlighting PMSC personnel's vulnerability to the companies' "coercive offers". The industry has been, however, discussed predominantly as a Western corporate phenomenon, with limited attention to its workers from the global South. We argue that a reality-congruent understanding of PMSCs requires greater attention to the extensive involvement of military labour from the "periphery" recruited by transnational companies headquartered in the "core".

Pioneering studies by Chisholm (2014a, b), Stachowitsch and Chisholm (2016) and others (e.g. Eichler, 2015) provide critical analyses of the gendered and racialised hierarchies reproduced by PMSCs' global recruitment practices from feminist, masculinities studies and postcolonial perspectives. Of particular relevance is Chisholm's $(2014 \mathrm{a}, \mathrm{b})$ work which illuminates, among others, PMSC treatment of Gurkhas as second class to Western personnel emanating from their marginalized labour market position and colonially-constructed status as racially underdeveloped subjects. We aim to contribute to this emerging literature by exploring the voices and experiences of Fijians contracted by PMSCs for deployment in conflict zones. Similar to the Gurkhas, Fijians are amongst those categorised as a "martial race", which makes Fiji a key PMSC labour supplier along with Nepal, Uganda and Kenya (Stachowitsch and Chisholm, 2016). Furthermore, like the Gurkhas, Fijians experience highly exploitative and physically and psychologically consequential relations with PMSCs, which has received scant research attention. By focusing on Fijian experience, we provide further empirical knowledge of the industry's recruitment of and effects on global South military/security labour as well as draw some theoretical insights from this knowledge.

Fiji is a Pacific island nation that has undergone multiple economic challenges due mainly to political instability (coups d'etat in 1987, 2000, and 2006) and external shocks. The average annual GDP growth dropped from 5.5 per cent in the 1970s to 0.8 per cent in the 2000s (Prasad, 2012). Only 40 per cent of the labour force is in the formal sector, and of this, only 36 per cent is in continuous paid employment (ADB, 2012). Forty-five per cent of the population lives in poverty (Narsey, 2014). In this context, migration to metropolitan countries, beginning around the 1970s, has become an important source of employment and remittances (Mohanty, 2006; Connell, 2006; Voigt-Graf, 2008, Kaitani, et al., 2011). Earlier migration was mostly permanent and dominated by Fijians of Indian descent, especially following the 1987 and 2000 ethno-nationalist coups. Since the 1990s, an increasing number of indigenous Fijians have been migrating, often temporarily, for remittance-generating purposes. These include Fijians recruited by the British Army (BA), Republic of Fiji Military Forces (RFMF) soldiers on United Nations (UN) and other peacekeeping missions, nurses, other health workers, rugby players, and PMSC personnel.

Researchers have studied the characteristics and impacts of Indo-Fijian emigration (e.g. Pangerl, 2007; Voigt-Graf, 2005) and temporary migration of skilled workers such as nurses and teachers (e.g. Reddy et al., 2004; Voigt-Graf et al., 2007). Extensive attention has also been given to the impact of remittances on social protection and migration intentions (Jimenez and Brown, 2013; Leeves, 2009; Kaitani, et al., 2011), political instability as a migration determinant (Narayan and Smyth, 2003) and human capital loss as an emigration cost (Reddy et al, 2004; Chandra, 2004). In other words, the existing literature centres around the patterns, intentions, benefits and costs of (skilled) migrations, with an emphasis on their development impacts. PMSC personnel movement has received limited discussion, despite some researchers noting it as one of the largest contemporary indigenous Fijian migrations (Voigt-Graf, 2008; Connell, 2006). The only detailed investigation is presented in Maclellan's (2006) journalistic study on a rising number of Fijian military migrants in the mid-2000s. Most of the existing documentation is in the Fijian mass media, especially two national newspapers, which in the early 2000s gave prominent coverage to PMSC personnel deaths, injuries and recruitment disputes.

In this article, we present an exploratory study to outline the scale, processes, and impacts of Fijian PMSC personnel migration to conflict zones through the eyes of the migrants. Our discussion is guided by the following research questions: 
1. What are the scale and processes of Fijian PMSC personnel migration to high-conflict zones?

2. What are the major characteristics and impacts of this migration from the migrants' perspective?

3. How do the migrants negotiate and respond to migratory challenges?

4. What does the above tell us about the mechanism of global private military/security labour trade and its effects on global South military/security labourers?

It should be noted that the study focuses specifically on PMSC personnel migration to high-conflict areas, especially Iraq, although Fijians have been employed as security personnel in various other countries and in non-conflict areas, including Papua New Guinea and Australia. Our analysis is informed by Wallerstein's (2004) World Systems Theory as a broad perspective to understand the structural context, but not as a rigid framework disregarding migrants' agency. The core-periphery model has been widely applied to migration research in the past, providing a conceptual framework for analysing labour mobility within "the structure of economic forces in core and periphery [which] ... condition migrants to sell their labour in places where needed and at the cheapest possible price" (Portes, 1978: 1). This has been prominent in discussions of "brain (and brawn) drain", underdevelopment and other detrimental migration impacts (e.g. Papademetriou, 1985; Binford, 2003). More recently, there has been a shift since the 2000s from "neo-Marxist pessimism" towards more optimistic estimations of migration, especially the role of remittances in poverty reduction and economic growth (de Haas, 2010). Nevertheless, we will demonstrate below that understanding PMSC procurement of Fijian military/security labour requires an analytical framework which accounts for the structural conditions of global private military/security labour trade.

Simultaneously, we acknowledge the limitations of deterministic models and the need for a multi-layered approach. We take note of the tendency in research until recent years to give primary attention to economic structural dynamics of migration (Pajo, 2008). While we highlight the structural inequities shaping PMSC personnel migration, especially in light of the current migration optimism and remittance research boom, we seek to understand how such processes and consequences are played out, experienced and negotiated "on the ground". Our goal is to understand the power dynamics of PMSC personnel migration through migrants' lived experiences. This approach is informed by de Haas's argument (2010: 241) that "an improved theoretical perspective on migration and development has to be able to account for the role of structure - the constraining or enabling general political, institutional, economic social, and cultural context in which migration takes place - as well as agency - the limited but real capacity of individuals to overcome constraints and potentially reshape structure."

\section{METHODS}

We employed two qualitative data collection methods. First, we conducted 18 semi-structured interviews between July 2015 and May 2016 with 12 PMSC personnel and four wives of PMSC personnel, including the widow of a man killed on duty. The men's ages ranged between 36 and 67 . All had been employed in Iraq between 2003 and 2014, while five had also worked elsewhere such as Afghanistan. The interviewees were recruited through a snowball sampling method. The interviews were conducted in English, and the transcribed data were put to thematic coding, which identified salient themes and concepts guided by the research questions. The interview data will be quoted in indented paragraphs or in inverted commas, with the interviewees referred to by pseudonyms. Second, due to the scarcity of previous research, we examined all issues of the Fiji Times, the daily newspaper which has historically had the largest circulation, dated from January 2000 to June 2016, and selected issues of the other daily newspaper the Fiji Sun, to collect relevant information. Additionally, the Fiji Bureau of Statistics, RFMF and BA were contacted for relevant statistics. 


\section{FIJI'S HISTORY OF "MUSCLE TRADE" AND PMSC PERSONNEL MIGRATION}

Fiji has a long history of military "muscle trade" originating from its involvement in the World Wars, especially World War II, where 8,000 Fijians joined the Allied forces in the Solomon Islands, and gained a reputation for bravery (Lal, 1992). This was followed by the Malayan War, when Fiji sent 1,600 troops to the Commonwealth forces. Following 1970 independence, Fiji's military labour migration accelerated through three main channels: 1) UN and other multilateral peacekeeping missions; 2) BA intake; and 3) PMSCs.

Fiji's participation in peacekeeping operations started in 1978 with the UN Interim Force in Lebanon, which has been followed by various other missions. Today a total of 1,040 peacekeeping personnel are sent annually (RFMF, 2016, personal communication). Indeed, Fiji has sent more soldiers on a per capita basis on UN peacekeeping missions than any other nation (Siegel and Feast, 2014). The participation in these, along with the war involvement, has established an international reputation for Fijian soldiery and engendered national pride in this reputation. Furthermore, it has become a major source of employment and remittances, reportedly earning Fiji well over US \$300million since 1978 (Siegel and Feast, 2014).

Recruitment of Fijians into the BA started in 1961/1962 (Ware, 2012). It accelerated in the late 1990s and early 2000s, reaching an annual intake of 490 in 2001/2002. The numbers however dropped from the late 2000s onwards. In 2009 the recruitment was suspended due to Fiji's postcoup political condition (Pacific Islands Development Program/East-West Centre, 2009), followed by the BA's downsizing policy in 2011. The 2014/2015 intake was just 10 . Nevertheless, a total of 2,740 Fijians have joined BA since 1998/1999 (BA, 2016, personal communication).

PMSC employment is the latest phase in Fiji's military labour migration history, which started around the early 2000s. Our interview data and media documentation show that Global Risk had Fijians deployed in Iraq in 2003, coinciding with the US-led invasion. Since then, thousands of (mostly indigenous) Fijian men (and a few women) have been contracted by mainly US- and UKbased PMSCs to work as "security guards" in Iraqi (and some Afghan) cities, with some in supportive roles in Kuwait in engineering, mechanical, and information technology (World Bank, 2006). Our interviewees have been employed by Global Risk (UK), Control Risks (UK), G4S (UK), SIS (UK), SOC (US), Total Defence Logistics (UK), Triple Canopy (US), Titan Security Services (UK), Olive Group (UAE), Kulak Construction (Turkish), EOD Technology (US), and Reed (US). Although the term "security guard" is commonly used in Fiji to describe their work, many engage in armed services, especially convoy security, security escorts and personal security details. In 2003, many were recruited to provide transportation and/or security for Iraqi's currency exchange. $^{2}$

No official record exists of the exact scale of this migration. However, it is possible to make a rough estimation of the PMSC migrant numbers between 2006 and 2011 with statistics obtained from relevant authorities. With advice from the Fiji Bureau of Statistics, armed force emigrant statistics were used as a baseline, from which the numbers of discipline force emigrants (i.e. peacekeeping troops and BA intakes) were deducted (see Table 1). While the remaining figures may include a small number of military migrants unaccounted for, they provide a useful indication of the scale of PMSC personnel migration.

These numbers indicate that during this period Fiji sent more PMSC personnel than peacekeeping troops, the country's primary military labour export. Furthermore, while these statistics show 2006 as the peak year with approximately 1,550 emigrants, our interview data and media documentation suggest that 2006 is in fact the year when PMSC recruitment numbers began to decline. The early 2000s numbers are hence speculated to have been even higher. According to 2005 media coverage, several PMSCs had over 700 Fijians deployed in Iraq and planned to recruit hundreds more. Fiji's Elections Office counted 4,000 Fijians in Iraq in 2006 (Rina, 2006), with the majority likely to have been PMSC personnel. 
TABLE 1

ESTIMATED PMSC PERSONNEL EMIGRATION

\begin{tabular}{|l|cccc|}
\hline Year & $\begin{array}{c}\text { Armed Forces } \\
\text { Emigration Total }\end{array}$ & $\begin{array}{c}\text { Peacekeeping } \\
\text { Departures* }\end{array}$ & $\begin{array}{c}\text { British Army } \\
\text { Intake** }\end{array}$ & $\begin{array}{c}\text { Estimated PMSC } \\
\text { Migrants }\end{array}$ \\
\hline 2006 & 2176 & 606 & 20 & 1550 \\
2007 & 2188 & 606 & 220 & 1362 \\
2008 & 1962 & 606 & 140 & 1216 \\
2009 & 1662 & 606 & 30 & 1026 \\
2010 & 1829 & 606 & 60 & 1193 \\
2011 & 1814 & 606 & 60 & 1148 \\
\hline
\end{tabular}

${ }^{*}$ RFMF sent 338 peacekeepers to Sinai and 268 to Iraq annually between 2006 and 2012.

${ }^{* *}$ BA intakes are recorded by the fiscal year. Here, intake figures are listed under the calendar years when the fiscal years started. (Sources: Fiji Bureau of Statistics, 2012; RFMF, 2016, personal communication; BA, 2016, personal communication).

Most personnel have prior discipline force experience (see Table 2). Many were in the military's territorial force or resigned from the military/police forces to take up PMSC contracts, the duration of which varies widely, from a few months to a few years. There are two main pathways for PMSC migration. First, many PMSCs previously had local recruitment agents facilitating enlistment and despatch. In 2005, there were five such agencies. While this has dropped to just one today, it is possible to apply online with some PMSCs. Second, once the recruits reach Iraq, many attempt to secure their next contract with another company while still abroad, anticipating contract expiry or following disputes with employers. Fijians contracted by various companies actively assist each other in this process. Consequently, many have made a career out of PMSC work, having served multiple contracts with multiple companies.

Our interviewees received an average monthly wage of US\$2,216, although their individual wages vary significantly, from US\$724 to US\$7,000 (see Table 2). While not all PMSC personnel are employed for 12 consecutive months, it is worth noting that their pro rata annual income is about triple Fiji's average household income (approximately US $\$ 8,252$ per annum in 2008-2009) (ADB, n.d.). Given significant income differences among individual wages, however, some personnel may earn about the same as the average household income.

\section{RISKS AND COSTS OF UNEQUAL "MUSCLE TRADE"}

Fraser (2013: 240) highlights the vulnerability of metropolitan PMSC contractors who are left "with a skill set and a mindset that make re-entry into civilian life difficult." Our findings show that Fijian PMSC workers experience greater vulnerability and exploitation specific to the dynamics of core-periphery "muscle trade."

\section{Socio-economic conditions of the trade}

Fijian PMSC workers' experiences must be understood in the context of local socio-economic conditions that motivate - and necessitate - entry into military labour trade. In the face of scarce employment opportunities and the absence of state unemployment benefits, those without formal qualifications or skills must sustain themselves and their families by any means available. In this context, PMSC contracts are deemed extremely lucrative. Our interview data suggest that, while some do not fully understand in advance the extent of the risks of the job, most are clearly aware 


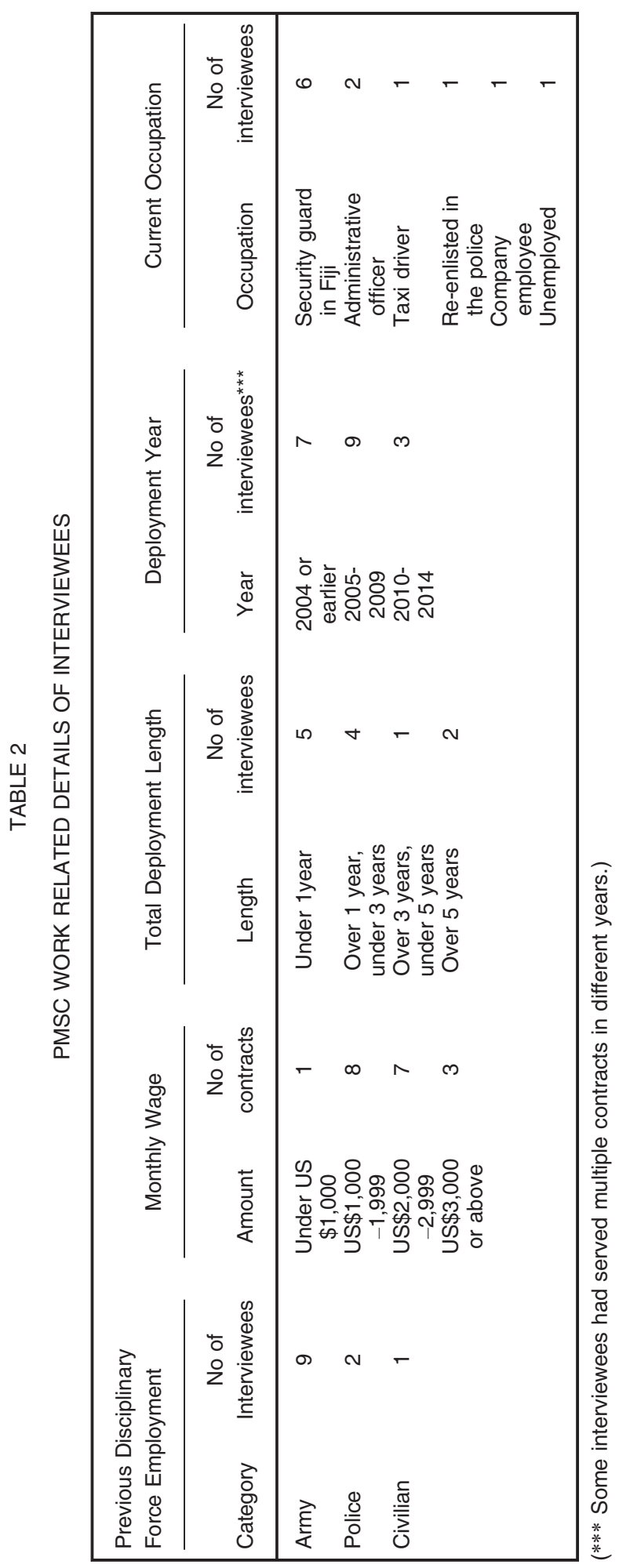


FIGURE 1

PMSC APPLICANTS

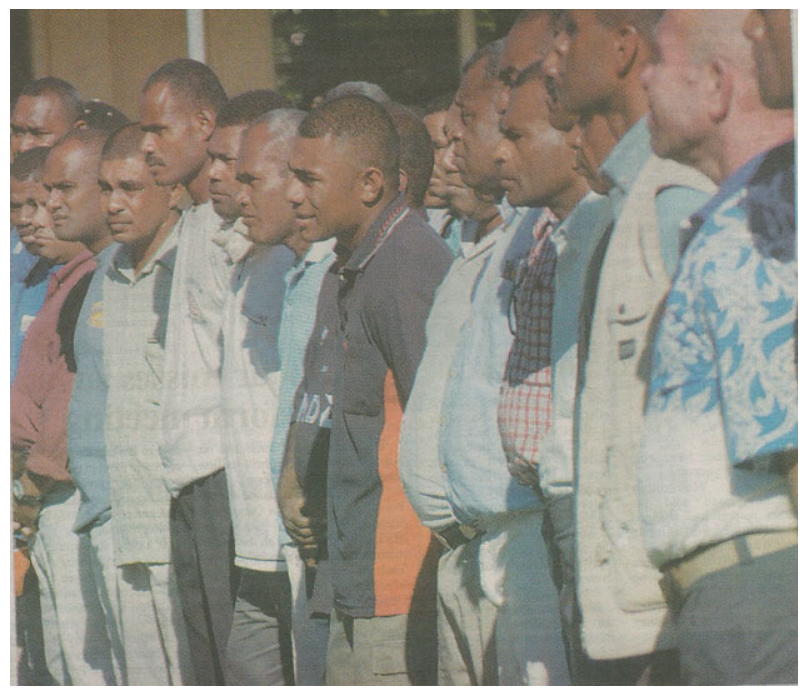

(Source: Fiji Sun, 13 May 2004: 1.)

of it and yet willing and indeed desperate to take a chance in return for a livelihood. Their primary, and in most cases only, motivation for PMSC migration is financial.

In 2004 and 2005, the explosion of PMSC recruitment and the scramble for contracts drew much public attention. For instance, in 2004, over 300 former soldiers gathered to apply with an American PMSC (Figure 1), and 520 soldiers and policemen enlisted with another. The desperate pursuit of contracts was paralleled by recruitment disputes. One particular case became a national controversy. In 2004, Timoci Lolohea of Meridian Services Agency, claiming to be the agent for Public Warehouse Company of Kuwait, undertook large-scale recruitment targeting villages, churches and suburbs, charging applicants $\mathrm{F} \$ 150$-fees. In most cases, deployment did not materialise, causing individuals and villages large financial damage. Lolohea reportedly obtained over F\$3million (US \$1.4million) from 20,000 people, triggering Ministry of Labour and police investigations. Even as these disputes unfolded, hundreds of men converged at his office, seeking enlistment (Chand, 2011).

Thousands of men (and some women) have thus desperately sought contracts, causing severe competition: "Every man for himself. The recruiter will give you only one opportunity. Your cell phone should be with you 24/7. He calls you at a moment's notice, and you leave. If he calls you, and you don't answer, that's it; you're done. He goes to the next person" (Epeli). Many are given little or no pre-deployment training. They are flown out of Fiji as and when companies require them, often with extraordinarily short notice, in many cases within a day of contract signing. In short, PMSC labour trade is decidedly a "buyer's market", where Fiji provides a large and desperate "reserve army" of military labour and companies dictate terms and conditions. Such power differential compels Fijians to bear significant costs and risks of the trade.

\section{Financial risks and costs}

Despite the perception of large financial gains, PMSC remuneration is sometimes considerably smaller than initially believed or anticipated. There have been media reports of wage disputes, 
which five of our interviewees experienced themselves. Two did not receive contracts until after leaving Fiji. Inoke, for instance, had been promised a US\$7,000/month salary, but when he and others were en route to Iraq, US\$1,500/month-contracts were distributed aboard the aeroplane. Others were misled by agents regarding duties, leave provisions and other working conditions. ${ }^{3}$ These episodes illustrate that the workers' ability to bargain with PMSCs/agents is undermined by lack of economic and cultural capital - i.e., their great need to secure a contract, and their lack of awareness of the importance of scrutinising contract provisions, ability to read English, and/or ability to comprehend legal language. Agents often 'just give us the contract and say 'Sign.' It's like a stick and carrot thing. They lure you with a carrot and when you get there, the stick is, if you don't sign, you are required to fly back to Fiji with no job" (Samuela).

Moreover, PMSC work entails long-term financial insecurity repercussions. PMSC contracts are for fixed periods and may be terminated at any time depending on company circumstances and other contingencies. This may abruptly leave the workers jobless, despite their attempts to secure another contract. Consequently, many fall into a cycle of PMSC work for a few months to a few years, followed by a sometimes-considerable period of unemployment or unskilled employment, until the next contract is secured. Between/after contracts they typically work as security guards or taxi drivers in Fiji: Emele's husband earned F\$2.50 (US\$1.20) per hour as a security guard at the time of the interview. In Epeli's words: "Whatever [we are] making is hand-to-mouth existence. People think going to Iraq makes millions. No, we don't! With this kind of contract, you hardly make just enough for the family to make ends meet, for risking your life."

\section{Physical risks and costs}

In addition to financial precariousness, PMSC deployment exposes them to extreme physical risks and life-threatening situations. As highlighted by Fraser (2013: 547), PMSC personnel, by international law, are "neither civilians nor soldiers: they belong to that grey category of unlawful combatants, who are liable to being killed with impunity ... but are denied the rights and privileges of soldiers." All the interviewees were deployed in Iraq's "red zones" (high-risk areas outside Baghdad's fortified, "green zones") and some in "black zones" ("where all Americans have pulled out" [Petero]). They experienced frequent, sometimes daily, insurgent attacks including ambushes, roadside bombs, sniper attacks and mortar bombs on duty or at camps, and some were involved in combat situations. Furthermore, they undertook their duties under extremely physically demanding conditions. Convoy drivers were required to drive at $120-190 \mathrm{~km} /$ hour for up to $7-8$ hours without stopping, to avoid roadside bombs and other attacks. Personal security detail officers accompanied clients in highly volatile areas, deploying defensive fighting positions, which sometimes prevented them from changing clothes or bathing for several days.

There is great variation in the levels of physical protection provided by PMSCs. Some interviewees were equipped with arms, body armour, and fully protected/armed vehicles, whereas others were unarmed or entirely without protective gear. Rupeni, for instance, worked as escorting convoy personnel for the Iraqi currency exchange in unprotected, soft-shell vehicles, from which all doors had been removed to ease personnel movement, exposing them directly to attacks (see Figure 2). The same type of vehicle was given to Eroni for personal security detail duties on two separate contracts in 2006 and in 2009.

All interviewees recalled violent and traumatising situations. Rupeni experienced an ambush, followed by half-hour shooting on his way to Basra Airport to return to Fiji. A bomb hit the vehicle behind him, burning an Iraqi soldier. He was ordered to extinguish the fire on the soldier's body:

The guy was wiggling on the road, burnt. You could see that underneath the skin was fat... In the midst of the fire and shooting, I took out my gun and a fire extinguisher. I couldn't crawl, so I rolled towards him. ... I could feel splinters of tar seal hit me in the face, so I knew the bullets 
FIGURE 2

CONVOY VEHICLE USED BY FIJIAN PMSC PERSONNEL

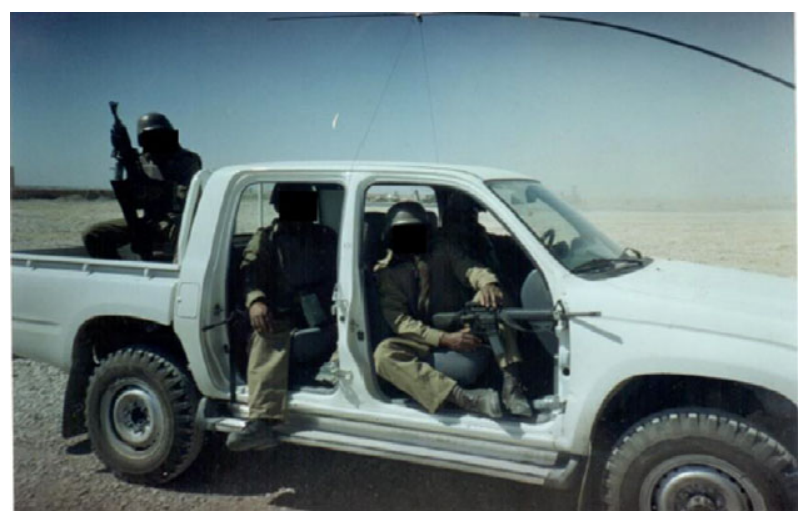

(Source: interviewee.)

were close enough. I was in a rush to extinguish the fire on him. I managed to extinguish it, but he died half an hour later. That was my last day. What an ending...

Taniela shared his story of witnessing his best friend's death in a roadside bomb attack:

I'm the one who got him out of the rubble. I carried him, [who was] without legs, half the body gone, and still alive... He was dying in my arms. He showed me his [wedding] ring and said "Please, my wife." Then he took off the ring, and died. This was my best friend. We joked all the time in the camp.

Review of newspaper coverage indicates that 29 Fijian PMSC personnel have died in Iraq since 2004. Numerous others have been injured, including four of our interviewees. PMSC personnel are typically insured for death but not injury, and therefore not entitled to compensation or continuing medical treatment. Consequently, Timoci and Petero, who were injured in the leg in mortar bomb attacks, were only provided with medical treatment immediately after the incidents. Timoci suffers from pain 10 years later, while Petero walks with a limp and pays for his own medical rehabilitation. Taniela, whose eye was badly injured by a roadside bomb, wears dark glasses at all times due to strong pain caused by light.

\section{Psychological costs}

None of the interviewees' employers provided counselling or other psychological support. Unlike post-deployment "decompression" programmes offered to uniformed soldiers, most Fijian PMSC personnel are flown to Fiji with no such provision and left to their own devices to reintegrate into civilian life and to cope with the psychological (and physical) effects of deployment.

The psychological effects identified by the interviewees include: impulsive fast driving, flashbacks, anxiety, extreme alertness, sleeping difficulty, anger management problems, and other symptoms of post-traumatic stress disorder. Inoke, who returned from Iraq four years prior to the interview, explained:

When I left [Fiji], I didn't have white hair. When I came back, so many - so much stress, so much worrying. My wife saw me and said, "Hey, is this you?" I don't sleep well. Like I still recall what 
happened those nights when I was in the war zone. Sometimes, I sleep with my feet on the [imaginary] accelerator and brakes, and my wife says, "What happened to you? Are you okay?" I was dreaming I was driving a truck. Still in the war zone.

Jone candidly discussed his struggle, three years after his return:

I have to stop commanding to my children. Things should be done the way I want. If I think they are late, I whack them. . . Sometimes I talk to my wife as if I am talking to one of my teammates. . I've realised that that's not good, because my children are frightened when I talk to them. My wife is not coping. Like, I'm hyper. When I'm lying down and someone touches me, automatically I jump up... Someday, tension is gonna explode. A lot of bad experience here [pointing to his head]. I know most of the violence against women and children is because of people working out there without proper counselling. I admit that myself... We're in a peaceful area now. But it is in my system.

The effects of untreated psychological traumas are thus felt by families/communities. Combined with financial insecurities and husbands' long-term absence, these have in some cases ended in marriage/family breakdown.

\section{PRIVATISATION OF MILITARY/SECURITY WORK AND CORE-PERIPHERY CHAINS OF EXPLOITATION}

As illustrated above, Fijians enter into military labour trade in a context of vulnerability, driven by their need to earn a livelihood in a society with little social protection, where those without formal skills/qualifications choose between subsistence farming, low-paid employment, informal employment, and unemployment. This vulnerability renders them highly susceptible to "coercive offers" of PMSCs, whereby they are compelled to offer low-cost military labour - remarkably cheaper than uniformed soldiers or Western PMSC personnel.

The financial implications of PMSC employment are not necessarily favourable, as noted above. Even for those who earn more than the average income, it remains open to question if that is indeed a "fair" return for undertaking high-risk duties that would otherwise be carried out by American/coalition soldiers, with much less physical protection, and much less or no compensation or post-deployment support. While returning soldiers' post-deployment hardships are widely publicised (e.g. Military.com, 2005), and Western PMSC personnel's dissatisfaction with "a token effort at support followed swiftly by abandonment" is documented (Fraser, 2013: 241), most Fijian workers have recourse to no support, entirely left on their own to bear the financial, physical and psychological costs of the military labour.

This is particularly conspicuous in cases of injury and death, compared with the protection provided for soldiers. For instance, the British government provides, for injury or illness, a payment of $£ 1,200-570,000$ (US\$1,600-765,000), and for death, a Survivors Guaranteed Income Payment payable for life, a bereavement grant, and a child's payment (UK Ministry of Defence, 2006). BA soldiers killed in action also receive symbolic compensation of formal acknowledgement and condolences from the highest office. The family of a Fijian BA solider killed in Iraq in 2007 received a personal letter from Prince of Wales and messages from Duchess of Cornwall and the British Prime Minister. The late soldier was accorded a full military funeral in Fiji, with 12 of his regiment officers flown in. By contrast, Asinate, whose husband was killed by a mortar bomb in Iraq in 2004 on a US $\$ 1,500 /$ month contract, received a one-off payment of $F \$ 250,000$ (US $\$ 120,000)$ and a single phone call from the company office in London. The price of Fijian PMSC workers' labour - and indeed lives - is significantly cheaper than those of uniformed soldiers.

Their labour is also strikingly cheaper than that of Western PMSC colleagues, who may in fact command higher salaries than regular soldiers. According to Krahmann (2012), Western PMSC 
personnel in Iraq could earn up to US $\$ 200,000$ a year, over seven times our interviewees' average salary. Our interviewees, like the Gurkhas in Chisholm's studies (2014a, b), invariably noted such differential wages: "All the white men - they [PMSCs] paid them good. Us Fijians - they paid us peanuts. They think we don't know what the money is worth" (Petero). Inoke, for instance, received US $\$ 1,500 /$ month, in contrast to US $\$ 10,000 /$ month paid to American colleagues performing the same duties. Many also noted differential leave and holiday allocations.

Emerging from this is a picture of a global chain of outsourcing and exploitation of military labour, with Fijians and possibly other peripheral military migrants at the bottom. The US/coalition governments outsource military labour to PMSCs for political and economic reasons, especially domestic opposition to national troop deployment in high-conflict areas (Brayton, 2002), and market-based, privatisation and cost-cutting policies (Isenberg, 2009). PMSCs, in turn, source military labour from not only Western ex-soldiers but also large "reserve armies" of soldiers, police officers and unemployed men in peripheral societies like Fiji and Nepal. The latter provide a particularly lucrative labour market for PMSCs for economic and political reasons similar to those that motivate state outsourcing of military labour. Fijians accept severely exploitative contract arrangements, which require minimum investment in remuneration, prior training, physical protection, insurance cover or psychological support. Furthermore, such arrangement is less likely to invite political scandals or protests than in metropolitan countries. Fijian government ministers, religious/community leaders, civil society organisations and mass media voiced their concerns in 2004/2005, leading to government attempts to monitor and regulate the recruitment. Subsequently, however, domestic political turmoil, which culminated in a military coup in 2006 and interim government rule until 2014, preoccupied media, state, and public attention. Further eclipsing the matter was the declining BA intake in the late 2000s. PMSC migration hence became marginalised as a policy/media matter and assumed a greater aspect of inevitability. In short, the economic and political uncertainty and vulnerability of the country have allowed PMSCs to source military labour on their own terms, with minimal local resistance or interference.

It is in the context of such unequal trade that PMSCs have grown into a vastly profitable industry. Global Risk, the key PMSC employer of Fijians, reportedly had a US $\$ 4.5$ million/month contract with the American Coalition Provision Authority in 2005. In 2008 American agencies awarded US $\$ 85$ billion for military/security contracts in Iraqi (Isenberg, 2009). The industry presents typical characteristics of core-peripheral labour trade, whereby transnational PMSCs seek out peripheral countries with required labour as well as political challenges and weak economic conditions for profit maximisation.

\section{PMSC MIGRANT AGENCY}

While Fijians are subjected to inequities of the core-periphery military labour trade, our interviewees showed that they are far from helpless or unknowing victims. First, they are critically aware of their own geopolitical structural position and the disparity inherent in the trade. Inoke, among many, noted:

You know why [Fijians are paid less]? Because Fijian people, African people, Filipinos - we are Third World countries. Cheap labour. That's why they send [the agent] to come and look for labour in Fiji. How come these [Western] people doing the same job are getting more, and we are getting less? It's like our life is cheaper than their life, yeah.

Second, their decision to enter into PMSC trade is a rational one, based on conscious choice of a livelihood for themselves and their families over risks. As discussed, many are acutely aware of the 
severity of possible consequences, yet resolute in their decision to take on the unfair system, negotiate its costs and bear its risks to secure an income. While this is clearly a manifestation of structural coercion, it also reflects their conscious engagement with the system, even if it may be a "losing battle" in the final analysis.

Third, they demonstrate collective resilience in the face of overwhelming adversities. Their resolution to get through PMSC work is propelled by mobilisation of pride in Fiji's martial tradition, similar to the way Gurkha PMSC personnel draw strength from the colonially-constructed Gurkha identity as a "martial race" (Chisholm, 2014b). As Jone explained: "Fijian soldiers - not only soldiers - any Fijian is a warrior. The technical things, the procedures of war, these things they [PMSCs] have now were in Fiji before Christ came". They also employ culturally-embedded strategies to cope with deployment challenges. In addition to regular devotions they organise, with some taking turns in acting as "the pastor of the day," talanoa (storytelling), drinking yaqona ${ }^{4}$ together, laughing and joking, which play a pivotal role in strengthening relationships and mutual sharing in Fijian culture, work as coping mechanisms (Figure 3). Samuela explained that, although radio was to be used for operational news only, "half the time, Fijian boys were chatting over the radio" in Fijian. They joked together in some of the most extreme situations: "Especially in war zones like that, joking carried us through."

Importantly, this discussion does not trivialise their affliction but illuminates their ability to exercise their agency even under the most onerous, exploitative conditions. They employ these strategies to collectively negotiate the hardships of deployment in the absence of formal protection/ support, although this does not diminish the oppressive nature of their circumstances. The price they pay, often privately and silently, was captured by Salote, who said her husband "really wanted

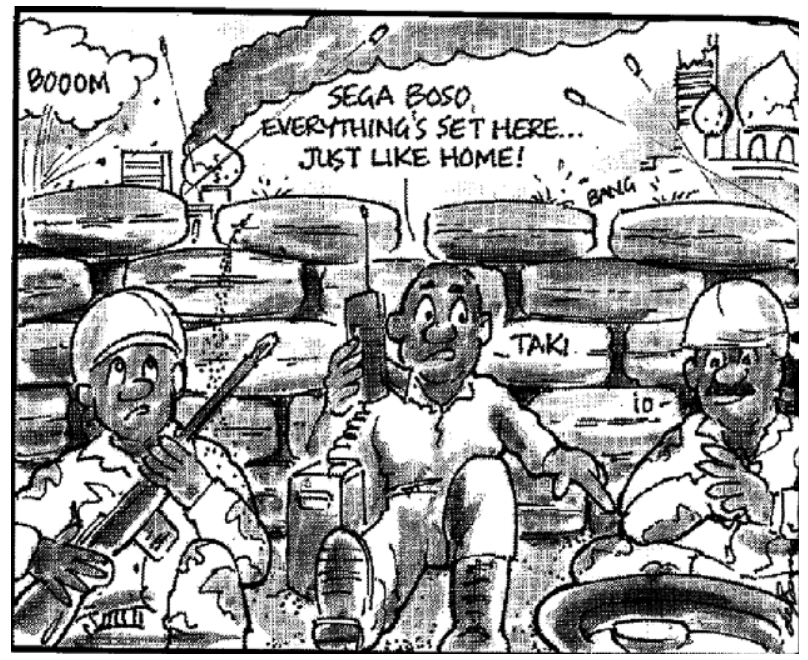

"No, boss. Everything is fine here... just like home!"

"Another round of yaqona."

"Yes." 
us to have a good life. Whenever he called [on Skype] he always wanted to speak to my eldest child... Whenever they spoke, I saw him on the camera, I saw tears dropping down his face." Their unspoken tribulation, as well as determination, were also illustrated by Eroni, who recounted saying to his doctor when he applied for his third contract, which was cut short due to a serious illness: "Just sign this [medical certificate], because it's good for me to go and die there [if] my family get money [rather] than I'm dying here and they receive no money. Sir, just sign. Let me go. Better for me to die but give them something than die here with nothing."

\section{CONCLUSIONS}

This article has outlined the possible scale, processes and impacts of Fijian PMSC personnel migration as well as the migrants' experiences of and responses to PMSC employment. Fijian PMSC personnel migration started around the early 2000s and expanded rapidly through mass recruitment, which is estimated to have sent over 1,000 Fijians annually to Iraq and other high-conflict areas. Our findings show this is an instance of unequal labour trade that takes place in a broader context of global "muscle trade." Against a backdrop of increasing neoliberal privatisation, states outsource military labour required in conflict-affected areas from PMSCs as an economically and politically expedient solution. PMSCs in turn source necessary military labour from: 1) ex-Special Force and other ex-personnel of metropolitan militaries; and 2) large and desperate "reserve armies" of ex-disciplinary force personnel and unemployed men in peripheral societies. Whilst Western ex-soldiers are vulnerable to PMSCs' coercive offers due to their socio-economic disadvantages, Fijians are doubly exploited due to their vulnerability specific to core-periphery power imbalances. PMSCs offer them markedly lower wages and make minimum investment in their prior training, physical protection, insurance cover and post-service psychological support, compelling them to bear significant financial, physical, and psychological risks and costs of military labour.

These findings add to the emerging literature on PMSC labour recruitment from the global South, which has, to date, centred on Gurkhas, exploratory and empirical insights into the experiences of Fijians - another key group of peripheral military/security labourers. Due to the country's economic vulnerability resulting in Fijian men's desperate pursuit of employment and long-term political instability obscuring the severity and magnitude of the costs of the trade, PMSC recruitment has become a decidedly "buyers' market" with Fiji positioned as a supplier of cheap and subordinate military/security labour. This also bears some theoretical implications for it illuminates the continuing relevance of politico-economic models in understanding contemporary labour migrations, despite the recent tendency among researchers and policymakers to focus on migration benefits, by showing that Fijian PMSC migration is indeed an instance - perhaps a quintessential one - of unequal coreperiphery labour trade. The core-periphery model is useful in understanding Fijians' location on the global private military/security supply chains and how this locks them into relations of exploitation and abuse over which they have little control.

Our findings also illuminate the agency of Fijian military migrants who engage with the unequal trade in a conscious, resolute and even resilient manner. Migration literature provides abundant documentation of the varied and creative ways in which migrant workers negotiate, circumvent and/or resist exploitative labour trade. In particular, migrant workers have been shown to employ a variety of strategies to establish informal networks and communities of support for each other via mobile phones (Law and Peng, 2008), shared Sunday activities (Lan, 2003) and conversations across balconies (in the case of domestic workers) (Pande, 2012) to name a few. The case of Fijian PMSC workers presents another informal yet notable strategy for migrant worker agency. Aware of their marginal geopolitical position and their vulnerability, they actively (and often desperately) submit themselves to the trade, but with critical consciousness. They also mobilise culturallyembedded strategies, ranging from embracing Fijian warrior identity and religiosity to joking, 
laughing and drinking yaqona together to cope with imminent risks and the absence of protection/ support provision. In this context, Fijians are not only victims of the global chain of military labour outsourcing and exploitation, but also knowledgeable and competent actors who take on the muscle trade system by mobilising a range of personal, collective, and cultural resources.

Our exploratory research is intended as a contribution towards a greater understanding of both the structural dynamics of this growing and consequential labour trade and the agency of human subjects demonstrated even under most powerful structural constraints. Although this article focused on Fiji, the dynamics of the trade discussed here may apply to other cases of military/security migrants from the global South.

\section{NOTES}

1. In this article, we use the term "private military and security company personnel" rather than "mercenary", while acknowledging the debates over the definitions of these terms (Krahmann, 2012), due to PMSCs' distinctive, corporate nature.

2. "Operation ICE" or the Iraqi Currency Exchange refers to the Coalition Provisional Authority's replacement of the Iraqi currency between October 2003 and January 2004. It involved large-scale security services for the transportation of money to banks around Iraq (Coalition Provisional Authority, 2004).

3. There is great variation in leave provisions, ranging in our interviewees' cases from a three-month-work and one-month-leave cycle to a 12 -month-work and one-month-leave cycle. During deployment, most interviewees were allowed holidays with varying intervals, but one worked 12 hours every day for three years as a military truck driver. There is less variation in insurance provisions. PMSC personnel are typically insured for death but not for injury.

4. Yaqona refers to the plant piper methysticum and the drink made from it, which has much ceremonial/social significance in Fijian society.

\section{REFERENCES}

Asian Development Bank

2012 Fiji 2012: Revitalising the Fiji Economy. Mandaluyong City, Philippines: Asian Development Bank.

n.d. Country Partnership Strategy: Fiji 2014-2018. Available at: http://www.adb.org/sites/default/files/ linked-documents/cps-fij-2014-2018-pa.pdf (accessed 27 April 2016).

Binford, L.

2003 "Migrant remittances and (under) Development in Mexico." Critique of Anthropology, 23(3): 305336.

Bjork, K. and Jones, R.

2005 "Overcoming dilemmas created by the 21st Century Mercenaries: Conceptualising the use of private security companies in Iraq." Third World Quarterly, 26(4-5): 777-796.

Brayton, S.

2002 "Outsourcing war: Mercenaries and the privatisation of peacekeeping." Journal of International Affairs, 55(2): 303-329.

Chand, S.

2011 "Recruiter scrutinized." The Fiji Times, 8 January, 7.

Chandra, D.

2004 "International migration from Fiji: Gender and human development issues." Asia Pacific Migration Journal, 13(2): 179-204.

Chisholm, A.

2014a "Marketing the Gurkha security package: Colonial histories and neoliberal economies of private security." Security Dialogue, 45(4): 349-372. 
2014b "The silenced and indispensible: Gurkhas in private military security companies." International Feminist Journal of Politics, 16(1): 26-47.

Coalition Provisional Authority

2004 Saddam-free Dinar Becomes Iraq's Official Currency: Iraqi CurrencyExchange Ends Today. Available at:http://govinfo.library.unt.edu/cpa-iraq/pressreleases/20040115_exchange_end.htm (accessed 6 September 2016).

Connell, J.

2006 "Migration, dependency and inequality in the Pacific: Old wine in bigger bottles? (Part 1)", in S. Firth, (Ed), Globalisation and Governance in the Pacific Islands, ANU E Press: Canberra: 59-80. de Haas, $\mathrm{H}$.

2010 "Migration and development: A theoretical perspective." The International Migration Review, 44 (1): $227-264$.

del Prado, J.L.G.

2008 Impact on human rights of private military and security companies' Activities. Global Research, 11 October. Available at: http://www.globalresearch.ca/impact-on-human-rights-of-private-military-andsecurity-companies-activities/10523 (accessed 12 April 2016).

Eichler, M. (ed.)

2015 Gender and Private Security in Global Politics. Oxford University Press.

Fiji Bureau of Statistics

2012 Key Statistics: Tourism and Migration. June.

Francis, D.J.

1999 "Mercenary intervention in sierra leone: Providing national security or International Exploitation?" Third World Quarterly, 20(2).

Fraser, B.

2013 "The reluctant mercenary: Vulnerability and the "Whores of War"." Journal of Military Ethics, 12(3): 235-251.

Isenberg, D.

2009 Private Military Contractors and U.S. Grand Strategy. Oslo: International Peace Research Institute. Jimenez, E.V. and Brown, R.P.C.

2012 "How Responsive are Remittances to Recipients' Welfare? Evidence from Fiji." International Migration, 51(S1): e179-e201.

Kaitani, M., Mohanty, M., Muliaina, T., Kumar, R., Kumar, S. and Naidu, V.

2011 Development on the Move: Measuring and Optimising Migration's Economicand Social Impacts in Fiji. Oceania Development Network Working Paper no.2. Suva, Fiji: Oceania Development Network.

Krahmann, E.

2012 "From "Mercenaries" to "Private Security Contractors": The (Re)construction of armed security providers in International Legal Discourses." Millennium: Journal of International Studies, 40(2): 343-363.

Lal, B.

1992 Broken Waves: A History of the Fiji Islands in the Twentieth Century. Honolulu, Hawaii: University of Hawaii Press.

Lan, P.

2003 "Political and social geography of marginal insiders: Migrant domesticworkers in Taiwan." Asian and Pacific Migration Journal, 12(1-2): 99-125.

Law, P. and Peng, Y.

2008 "Mobile networks: Migrant workers in Southern China", in J.E. Katz, (Ed), Handbook of Mobile Communication Studies, MIT Press: Cambridge, Massachusetts: 55-64.

Leeves, G.

2009 "Migration plans and received remittances: Evidence from Fiji and Tonga." International Migration Review, 43(1): 160-177.

Maclellan, N.

2006 "From Fiji to Fallujah: The war in Iraq and the privatisation of Pacific Security." Pacific Journalism Review, 12(2): 47-65. 
Military.com

2005 Fighting Combat Stress. Available at: http://www.military.com/NewContent/0,13190,Defensewatch_ 020705_Kipling,00.html (accessed 3 May 2016).

Ministry of Defence, UK Government

2006 Guidance: Armed forces compensation: what you need to know. Available at: https://www.gov. uk/government/publications/armed-forces-compensation/armed-forces-compensation-what-you-needto-know (accessed 1 May 2016).

Mohanty, M.

2006 "Globalisation, New labour migration and development in Fiji”, in: S. Firth (Ed), Globalisation and Governance in the Pacific Islands, Canberra: ANU E Press: 107-120.

Narayan, P.K. and Smyth, R.

2003 "The determinants of immigration from Fiji to New Zealand: An empirical reassessment using the bounds testing approach.” International Migration, 41(5): 33-58.

Narsey, W.

2014 "The facts on Poverty and Social Justice." The Fiji Times, 26 July.

Pacific Islands Development Program/East-West Centre

2009 British Army Puts off Recruiting in Fiji. Pacific Islands Report, 2 February.

Pajo, E.

2008 International Migration, Social Demotion, and Imagined Advancement: An Ethnography of Socioglobal Mobility. New York: Springer.

Pande, A.

2012 "From 'Balcony Talk' and 'Practical Prayers' to illegal collectives: Migrant domestic workers and meso-resistances in Lebanon." Gender and Society, 26(3): 382-405.

Pangerl, M.

2007 "Notions of insecurity among contemporary Indo-Fijian Communities." The Asia Pacific Journal of Anthropology, 8(3): 251-264.

Papademetriou, D.G.

1985 "Illusions and reality in international migration: Migration and development in Post World War II Greece." International Migration, 23(2): 211-223.

Peters, W.C.

2006 "On law, wars, and mercenaries: The case for courts-martial jurisdiction over civilian contractor misconduct in Iraq." Brigham Young University Law Review, 2006(2): 367-414.

Portes, A.

1978 "Migration and underdevelopment." Politics and Society., 1978; 8(1): 1-48.

Prasad, B.C.

2012 "Fiji's economy: A view over 25 Years." Devpolicyblog, 12 September, available at http://devpolic y.org/fijis-economy-a-view-over-25-years/ (accessed 21 November 2015).

Reddy, M., Mohanty, M. and Naidu, V.

2004 "Economic cost of human capital loss from Fiji: Implications for sustainable development." International Migration Review, 38(4): 1447-1461.

Republic of Fiji Military Forces (RFMF)

2016 Personal communication, 22 April 2016

Rina, S.

2006 "4000 did not vote in Iraq." The Fiji Sun, 7 May, 1.

Sen, A.

2015 "Boom time" for private security contractors." Atlantic Council. 17 February. Available at: http:// www.atlanticcouncil.org/publications/books/boom-time-for-private-security-contractors (accessed 7 April 2016).

Siegel, M. and Feast, L.

2014 "For Fiji's military rulers, U.N. peacekeeping a useful mask." Reuters. 4 September. Available at: http://www.reuters.com/article/us-fiji-un-crisis-idUSKBNOGZ0GV20140904 (accessed 21 March, 2016). 


\section{Singer, P.W.}

2005 "Outsourcing war: Understanding the Private Military Industry." Foreign Affairs, March/April, available at: https://www.foreignaffairs.com/articles/2005-03-01/outsourcing-war (accessed 31 May 2016).

Stachowitsch, S. and Chisholm, A.

2016 "Everyday matters in global private security supply chains: A feminist global political economy perspective on Gurkhas in private security." Globalizations, DOI:10.1080/14747731.2016.1155796.

Voigt-Graf, C.

2005 "The construction of transnational spaces by indian migrants in Australia." Journal of Ethnic and Migration Studies, 31(2): 365-384.

Voigt-Graf, C., Iredale, R. and Khoo, S.

2007 "Teaching at home or overseas: Teacher migration from Fiji and the Cook Islands." Asian and Pacific Migration Journal, 16(2): 199-223.

Voigt-Graf, C.

2008 "Migration patterns and transnational families in Fiji: Comparing two ethnic groups." International Migration, 46(4): 15-40.

Wallerstein, I.

2004 World-Systems Analysis: An Introduction. Durham, NC: Duke UniversityPress.

Ware, $\mathrm{V}$.

2012 Military Migrants: Fighting for YOUR country. Basingstoke, Hampshire: Palgrave Macmillan.

Whyte, D.

2003 "Lethal regulation: state - corporate crime and the United Kingdom government's new mercenaries." Journal of Law and Society, 30(4): 576-600.

World Bank

2006 At Home and Away: Expanding Job Opportunities for Pacific Islanders through Labour Mobility. Washington DC: World Bank. 